\title{
Impact of artificial destratification on water availability of reservoirs in the Brazilian semiarid
}

\author{
IRAN E. LIMA NETO \\ Departamento de Engenharia Hidráulica e Ambiental/DEHA, Universidade Federal do Ceará/ \\ UFC, Campus do Pici, Bloco 713, 60.451-970 Fortaleza, CE, Brazil. \\ Manuscript received on December20, 2017; accepted for publication on December 6, 2018
}

\begin{abstract}
How to cite: LIMA NETO IE. 2019. Impact of artificial destratification on water availability of reservoirs in the Brazilian semiarid. An Acad Bras Cienc 91: e20171022. DOI 10.1590/0001-3765201920171022

Abstract: Field surveys and integral modelling were carried out to study the effect of bubble plumes on the flow hydrodynamics and the time-evolution of water temperature profiles in a shallow lake with maximum depth of about $4 \mathrm{~m}$. Then, model simulations were performed to verify the feasibility of destratification of ten water-supply reservoirs with capacities of 10-2,000 $\mathrm{hm}^{3}$. Finally, hydrological modelling was conducted to assess the impact of destratification on evaporation suppression and its effects on reservoir yield. The results indicate that net temperature reductions of the order of $1.0^{\circ} \mathrm{C}$ can be obtained, which corresponds to evaporation suppressions of approximately $10 \%$. In turn, this resulted in increases in the regulated flow of $2-12 \%$ that could be described by a general correlation. Lastly, a simplified feasibility analysis provided an operational cost of about 1.0 US\$ per cubic meter of saved water, which suggests that artificial destratification cannot be discarded as an alternative for supplementing water supply in rural water-scarce regions.
\end{abstract}

Key words: aeration, evaporation, bubble plumes, lakes, stratification, water yield.

\section{INTRODUCTION}

Lakes and reservoirs normally face thermal stratification of the water column, especially during warm periods. This impacts negatively the water quality, as the poorly-oxygenated lower water layers (hypolimnion) become isolated from the upper oxygenated water layers (epilimnion), due to the existence of a sharp temperature gradient called thermocline, as shown schematically in Figure 1. As a consequence, serious water quality issues such as eutrophication and toxic cyanobacterial blooms have been frequently reported in stratified

E-mail: iran@ufc.br

ORCid: https://orcid.org/0000-0001-8612-5848 reservoirs, notably in semiarid areas (Bouvy et al. 2000, Dantas et al. 2011, Pacheco and Lima Neto 2017). Moreover, water availability in such areas is also significantly reduced (up to about $50 \%$ ) by evaporation of the surface waters (Wurbs et al. 2014, Campos et al. 2016).

Artificial destratification by bubble plumes has been frequently proposed as an efficient technique to ameliorate water quality in lakes and reservoirs, ranging from relatively small water bodies to the Great Lakes in North America (Wüest et al. 1992, Imteaz and Asaeda 2000, Boegman and Sleep 2012, Lima Neto et al. 2016). Several researchers reported that destratification could limit light and nutrient availability, and then minimise algal blooms and/ 


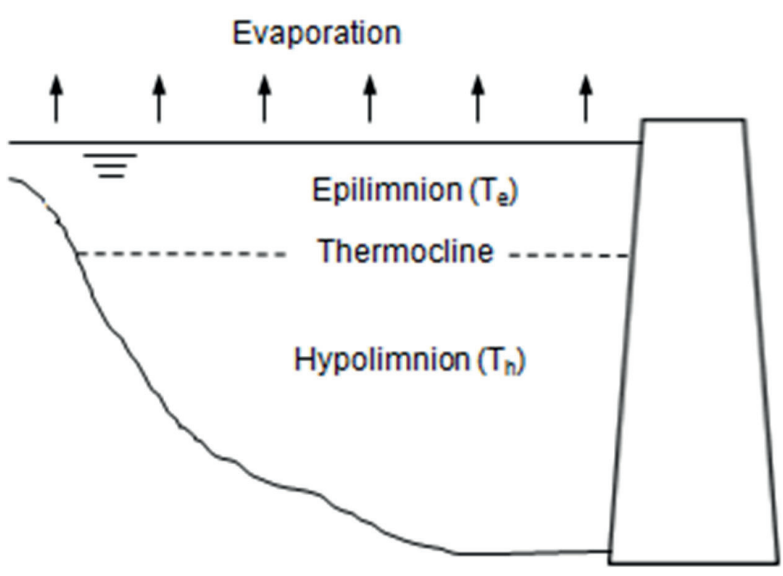

Figure 1 - Evaporation from a stratified reservoir, in which the temperature of the epilimnion $\left(T_{e}\right)$ is higher than that of the hypolimnion $\left(\mathrm{T}_{\mathrm{h}}\right)$.

or change the composition from cyanobacterial dominance to green algae and diatoms (Visser et al. 2016). On the other hand, bubble plumes have been widely used to supplement the dissolved oxygen levels in the hypolimnion and then reduce phosphorus release from the sediments to inhibit algal growth (Bormans et al. 2016). More recently, Toné et al. (2017) and Pacheco and Lima Neto (2017) showed that artificial water circulation and turbulence induced by bubble plumes can also promote cyanobacteria decay, even in unstratified shallow lakes.

In addition to improving water quality in lakes and reservoirs, artificial destratification using bubble plumes has been proposed alternatively as a means to reduce evaporation from open-water impoundments in many dry areas around the globe (see Helfer 2012). These systems bring the colder water from the lower layers to the water surface, so that surface temperature (and evaporation rates) can be minimised. Cox (1999) used a simplified model that estimated an evaporation suppression of about $10 \%$ for reservoirs located in Cyprus, contrasting to previous studies conducted in North American reservoirs, which suggested evaporation reductions as high as 30\%. Van Dijk and Van Vuuren (2009) performed field surveys in a South
African reservoir and found that surface water temperature dropped from about $1-2.5^{\circ} \mathrm{C}$ every time a bubble plume was released. These authors also discussed the potential of artificial destratification for evaporation suppression and cost savings. Helfer et al. (2011) coupled a bubble plume model to a lake hydrodynamic model (Dynamic Reservoir Simulation Model - DYRESM) and found that artificial destratification of an Australian reservoir was only effective in reducing evaporation in spring (about 5\%). Although some other techniques for evaporation suppression are also mentioned in the literature (see Silan 2003, Assouline et al. 2011, Wurbs et al. 2014), they usually involve coverage of the lake surface area or blockage of the wind flow, which may cause significant impact on water quality, opposing to artificial destratification, which can lead to water quality improvement, as already discussed.

The present study consists of three parts: (1) numerical modelling and field surveys are conducted in a shallow lake in the semiarid region of Brazil to assess the impact of diffused aeration on the induced flow velocity and water temperature profiles; (2) numerical simulations are performed to verify the feasibility of bubble plume destratification of ten relatively deep reservoirs located in the same region; and (3) hydrological modelling is carried out to investigate the impact of artificial destratification on evaporation suppression and its effects on the regulated flow of these reservoirs. To the author's knowledge, this is the first study that makes use of artificial destratification as a means to reduce evaporation from Brazilian reservoirs. Additionally, there is no study in the literature that investigates the influence of artificial destratification on the water yield of reservoirs. This study is important for water-scarce regions, such as the Brazilian Northeast, which has a population of about 60 million inhabitants and a high-density network with approximately 200 thousand water-supply reservoirs, most of them 
presenting an advanced state of eutrophication (see Lima Neto et al. 2011, Campos et al. 2016, Pacheco and Lima Neto 2017).

\section{MATERIALS AND METHODS}

\section{FIELD SURVEYS}

Field surveys were carried out to investigate the potential of the use of bubble plumes for reservoir destratification and reduction of surface water temperature, which is beneficial for evaporation suppression. The studies were conducted in the dry season from June to December of 2016 in the Santo Anastácio Lake, Fortaleza, Ceará, Brazilian Northeast, as shown schematically in Figure 2. This lake has a capacity of approximately $0.3 \mathrm{hm}^{3}$, maximum water depth of about $4 \mathrm{~m}$, and surface water temperature typically above $30^{\circ} \mathrm{C}$. Its phosphorus concentration is normally above $1 \mathrm{mg} / \mathrm{L}$, which results in a hypereutrophic classification. The artificial destratification system consisted of a $7.5 \mathrm{~kW}$ compressor that provided air flow rates $\mathrm{Q}$ to a perforated-pipe diffuser placed at the bottom of the lake at a depth $\mathrm{h}=2 \mathrm{~m}$ (Figure 3 ). Notice that only very close to the dam there is a small portion of the lake with water depths of 3-4 $\mathrm{m}$. Therefore, it was decided to place the diffuser in a plane region with a typical water depth of $2 \mathrm{~m}$, that was also away from the boundaries, resulting in unconfined air bubble plumes. The air flow rates $Q$ ranged from 0.02 to $0.08 \mathrm{~m}^{3} / \mathrm{s}$ and were measured with a rotameter from ECR (Eberhardt). A MiniWater20 anemometer from Omni Instruments was used to measure water velocity (range of 0.02 $5 \mathrm{~m} / \mathrm{s}$ ), while a HI 9828 multiparameter probe from Hanna Instruments was used to measure water temperature (range of $5-55^{\circ} \mathrm{C}$ ), both with accuracy of $\pm 2 \%$. The anemometer and temperature probe were mounted on a stem connected to a thoroughly anchored boat. Measurements of water velocity and temperature were taken during the day time $(10 \mathrm{am}-4 \mathrm{pm})$ at $\mathrm{t}=0,5,15$ and $30 \mathrm{~min}$ after turning on the destratification system, at different axial distances $\mathrm{z}$ from the diffuser, and at the bubble plume centreline $(a t b=0)$.

Hydrological parameters were measured in a meteorological station near the Santo Anastácio dam. During the artificial destratification tests in the lake, the water inflow $\left(<0.1 \mathrm{~m}^{3} / \mathrm{s}\right)$ and the wind speed $(\sim 2 \mathrm{~m} / \mathrm{s})$ were relatively low. On the other hand, precipitation was nil, air temperature ranged from about $26-32^{\circ} \mathrm{C}$ and evaporation in a class A pan varied from approximately $4-10 \mathrm{~mm}$ per day. Under these conditions, it was assumed that the destratification process induced by the bubble plumes was not significantly affected by the hydrological parameters.

\section{BUBBLE PLUME MODELLING}

The integral models of Lima Neto (2012) and Lima Neto et al. (2016) were adopted here as a reference for simulation of the destratification process. These models assume that the relative air concentration is small, the lateral distribution of flow properties is uniform, the advection of the mean flow dominates turbulence effects, the bubbles present uniform diameters and a constant slip velocity, the bubble expansion follows the ideal gas law, the effects of gas dissolution in addition to ambient currents and waves are negligible, and the stratification can be represented by a two-layer pattern. Thus, the following equations were used to represent the variation of the liquid volume and momentum fluxes with the axial distance $\mathrm{z}$ from the diffuser:

$$
\begin{aligned}
& \frac{d}{d z}\left(u b^{2}\right)=2 \alpha u b \\
& \frac{d}{d z}\left(u^{2} b^{2}\right)=\frac{\rho_{a}-\rho}{\rho_{a}} g b^{2} \lambda^{2}
\end{aligned}
$$

In Eq. (1), $\mathrm{u}$ and $\mathrm{b}$ are the velocity and radius of the plume, respectively, and $\alpha$ is the entrainment coefficient, which can be taken as 0.1 (Woods 


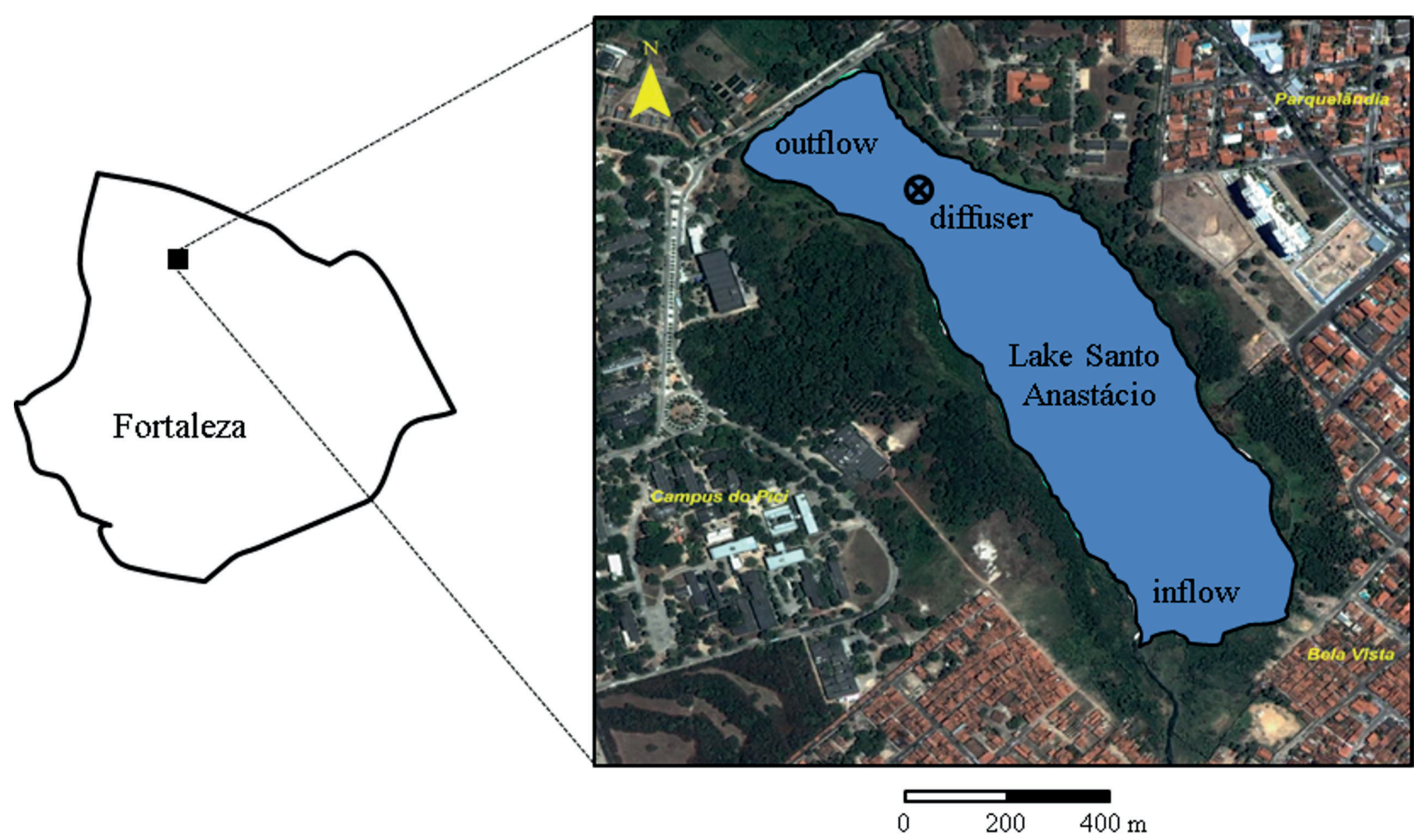

Figure 2 - Location of the Santo Anastácio Lake in Fortaleza, Brazilian Northeast (Latitude: 0343'02" S and Longitude: 38³2'35" W). The position of the air diffuser system in the lake is also shown.

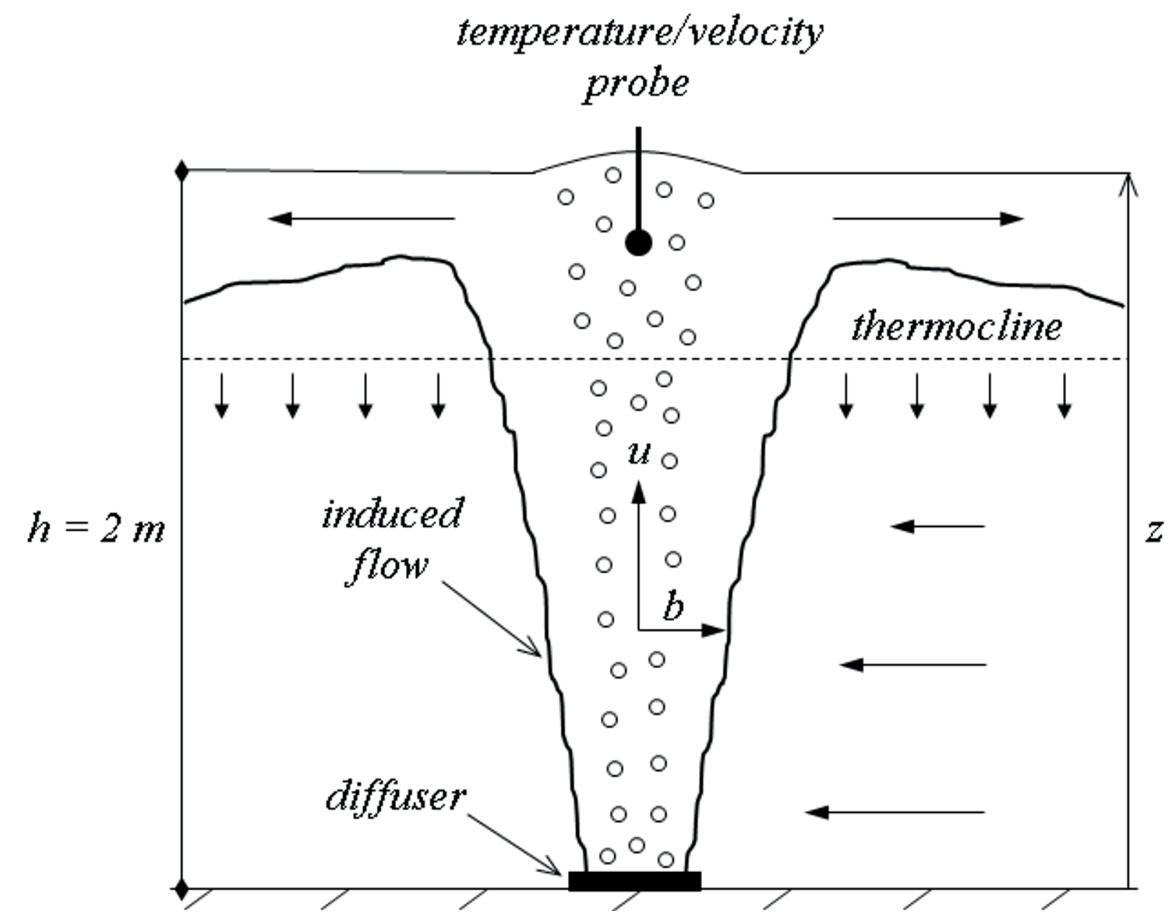

Figure 3 - Schematic of the bubble plume destratification process indicating the induced liquid flow and the descending thermocline. Note that water temperature and velocity measurements were taken along the bubble plume centreline. 
2010). In Eq. (2), $\rho$ and $\rho_{\mathrm{a}}$ are the densities of the plume and ambient water, respectively, and $\lambda$ is the fraction of the plume radius occupied by the bubble core, usually taken as 0.8 (Lima Neto 2012). Note that $\rho$ decreases gradually along the plume while $\rho_{\mathrm{a}}$ drops abruptly at the density interface (thermocline). These two equations are solved to obtain values of $u$ and $b$ along z. Then, Eq. (3) can be used to predict the destratification process represented by the lowering of the thermocline:

$A \frac{d z_{t}}{d t}=-\pi u_{t} b_{t}^{2}$

in which $\mathrm{A}$ is an effective area occupied by the liquid flow induced by the bubble plume, which was considered here as $\mathrm{A}=\pi \mathrm{h}^{2}$, following the geometry of the circulation flow cells described by Lima Neto et al. (2008); $u_{t}$ and $b_{t}$ are the velocity and radius of the plume at the thermocline, respectively; and $\mathrm{dz}_{\mathrm{t}} /$ $\mathrm{dt}$ is the velocity of the descending thermocline.

The equations (1) - (3) are solved using a Runge Kutta fourth-order method. After validation of the bubble plume model with the water temperature and velocity measurements obtained in the field study, this model was used to evaluate the feasibility of destratification of ten relatively deep reservoirs $(\mathrm{h}>$ $10 \mathrm{~m}$ ) located in the State of Ceará, which are listed in Table I. Due to lack of information about water temperature profiles in such reservoirs, typical patterns of stratification were assumed, considering the profiles normally observed in the reservoirs located in the Brazilian semiarid. According to the data presented by Souza Filho et al. (2003), Meireles et al. (2007), and Dantas et al. (2011), the thickness of the epilimnion ranges from about $1 / 5$ to $1 / 3$ of the water depth $\mathrm{h}$ of such reservoirs. Also, the temperature of the epilimnion $\mathrm{T}_{e}$ is about 25$30^{\circ} \mathrm{C}$, while the temperature of the hypolimnion $\mathrm{T}_{\mathrm{h}}$ is usually $1-5^{\circ} \mathrm{C}$ colder. Thus, considering arrays of bubble plumes spaced $\mathrm{h}$ apart, as suggested by Lima Neto et al. (2016), it was possible to predict the destratification time and potential temperature
TABLE I

Characteristics of the selected reservoirs, which are located in the State of Ceará, Brazilian semiarid: $\mathrm{V}=$ reservoir capacity, $h_{\max }=$ maximum depth, and $Q_{90}=$ regulated flow with reliability of $90 \%$.

\begin{tabular}{cccc}
\hline Reservoir & $\mathbf{V}\left(\mathbf{h m}^{\mathbf{3}}\right)$ & $\mathbf{h}_{\mathbf{m a x}}(\mathbf{m})$ & $\mathbf{Q}_{\mathbf{9 0}}\left(\mathbf{h m}^{\mathbf{3}} / \mathbf{y e a r}\right)$ \\
\hline Ema & 10 & 13 & 2.55 \\
Ingazeiro & 11 & 16 & 5.75 \\
Cipoada & 17 & 11 & 10.17 \\
Trapiá II & 18 & 24 & 9.23 \\
Prazeres & 33 & 46 & 5.92 \\
Canoas & 69 & 43 & 14.82 \\
Cedro & 126 & 15 & 17.69 \\
Trussu & 263 & 32 & 51.81 \\
Pedras Brancas & 434 & 27 & 70.49 \\
Orós & 1,956 & 45 & 380.52 \\
\hline
\end{tabular}

reductions for each reservoir and for different individual air flow rates $\mathrm{Q}$.

HYDROLOGICAL MODELLING

The model of Campos et al. (2014) was adapted to investigate the impact of artificial destratification on evaporation suppression and its effects on the regulated flow of the selected reservoirs. Thus, using monthly stream flow series and average losses (evaporation minus precipitation) provided by Secretaria dos Recursos Hídricos do Ceará - SRH (1992), the water budget equation was solved using Monte Carlo simulation to obtain the regulated flow for each reservoir:

$Z_{i+1}=Z_{i}-\left(E_{i}-P_{i}\right) \frac{\left(\phi_{i+1}+\phi_{i}\right)}{2}+I_{i}-R_{i}-S_{i}$

In Eq. (4), the subscripts $i+1$ and $i$ refer to subsequent months, $\mathrm{Z}$ is the reservoir volume, $\mathrm{E}$ is the average depth of the water evaporated from the lake surface, $\mathrm{P}$ is the average rainfall over the lake surface, $\phi$ is the lake surface area, I is the reservoir inflow, $\mathrm{R}$ is the total reservoir withdrawal, and $\mathrm{S}$ is the volume spilled. For $90 \%$ reliability, adopted in this paper as a standard for the Brazilian Northeast, 
the monthly regulated flow $\mathrm{Q}_{90}$ is equal to the mean annual net withdraw divided by 0.95 (see Campos and Studart 2006).

According to Fischer et al. (1979), the evaporation rate $E_{i}$ can be described by the following equation:

$$
E_{i}=\beta_{i}\left(e_{s, i}-e_{H, i}\right)
$$

In Eq. (5), $\beta_{\mathrm{i}}$ is an empirical function of the wind speed measured at a particular height $\mathrm{H}$ in month $\mathrm{i} ; \mathrm{e}_{\mathrm{H}, \mathrm{i}}$ is the vapour pressure in the air at height $\mathrm{H}$ in month $\mathrm{i}$; and $\mathrm{e}_{\mathrm{s}, \mathrm{i}}$ is the saturation vapour pressure in month $i$, which can be described as a function of the temperature of the epilimnion in month i $\left(\mathrm{T}_{\mathrm{e}, \mathrm{i}}\right)$ by the formula of Magnus-Tetens (Helfer et al. 2011):

$e_{s, i}=\exp \left[2.3026\left(\frac{7.5 T_{e, i}}{T_{e, i}+237.3}+0.7858\right)\right]$

Observe that Eqs. (5) and (6) can be used to assess the impact of changes in the temperature of the epilimnion $\left(\mathrm{T}_{\mathrm{e}, \mathrm{i}}\right)$ in the evaporation rate $\mathrm{E}_{\mathrm{i}}$, assuming that the other variables $\beta_{\mathrm{i}}$ and $\mathrm{e}_{\mathrm{H}, \mathrm{i}}$ are constants.

Finally, the effect of artificial destratification on the regulated flow $\mathrm{Q}_{90}$ of the reservoirs listed in Table I was evaluated by using Eqs. (4) - (6), considering different scenarios of reduction of the surface water temperature $\left(T_{e, i}\right)$, which were obtained from the results of the field surveys and bubble plume simulations.

\section{RESULTS AND DISCUSSION}

Figure 4 shows a typical time-evolution of the temperature profiles measured along the destratification process in the Santo Anastácio Lake, which is expected to occur within the effective area A around the diffuser, as defined in Eq. (3). Before the release of the bubble plume, it was observed a thermocline with thickness of approximately $0.4 \mathrm{~m}$, which represents about $1 / 5$ of the water depth $\mathrm{h}$ of $2 \mathrm{~m}$. On the other hand, the temperature difference between the epilimnion and hypolimnion $\left(\mathrm{T}_{\mathrm{e}}-\mathrm{T}_{\mathrm{h}}\right)$ was about $1{ }^{\circ} \mathrm{C}$. This is consistent with the results presented by Souza Filho et al. (2003) for a reservoir of about $10 \mathrm{~m}$ deep. However, Meireles et al. (2007) and Dantas et al. (2011) found temperature differences $\left(T_{e}-T_{h}\right)$ of up to about $5^{\circ} \mathrm{C}$ for reservoirs with water depths ranging from 15-45 $\mathrm{m}$. After release of the bubble plume with an air flow rate of $\mathrm{Q}=0.05 \mathrm{~m}^{3} / \mathrm{s}$, it is clearly seen a gradual displacement of the thermocline towards the lake bottom, until the temperature is approximately uniform over the water depth, and complete mixing is reached within about $15 \mathrm{~min}$. After $30 \mathrm{~min}$, there is a slight increase in the water temperature, probably due to heat input from solar radiation into the lake, but the surface temperature is still about $0.5^{\circ} \mathrm{C}$ lower than that before the release of the bubble plume. It is important to mention that similar temperature reductions of $0.3-0.6^{\circ} \mathrm{C}$ were obtained for the other air flow rates $\mathrm{Q}$, when the initial temperature difference $\left(T_{e}-T_{h}\right)$ ranged from $0.5-1.1^{\circ} \mathrm{C}$, respectively. This implies that complete mixing of the water column can potentially reduce the surface temperature of the lake by about half of its initial temperature difference $T_{e}-T_{h}$. Note that Van Dijk and Van Vuuren (2009) obtained larger temperature drops of $1-2.5^{\circ} \mathrm{C}$ in a deeper lake $(\mathrm{h}=$ $16 \mathrm{~m}$ ) in South Africa.

Typical water velocity measurements obtained from the field surveys as well as bubble plume model simulations for $\mathrm{Q}=0.05 \mathrm{~m}^{3} / \mathrm{s}$ are shown in Figure 5. A good adherence of the model to the field data was observed for all the tests, with mean deviations of up to about $15 \%$. This suggests that the proposed model can be used to predict the liquid flow induced by bubble plumes in artificial destratification systems. Observe that the velocity profile shown in Fig. 5 did not change significantly during the destratification process. This is a result of a negligible change in the buoyancy of the plume as the thermocline descended. The same behaviour has been verified by Lima Neto et al. (2016) at 


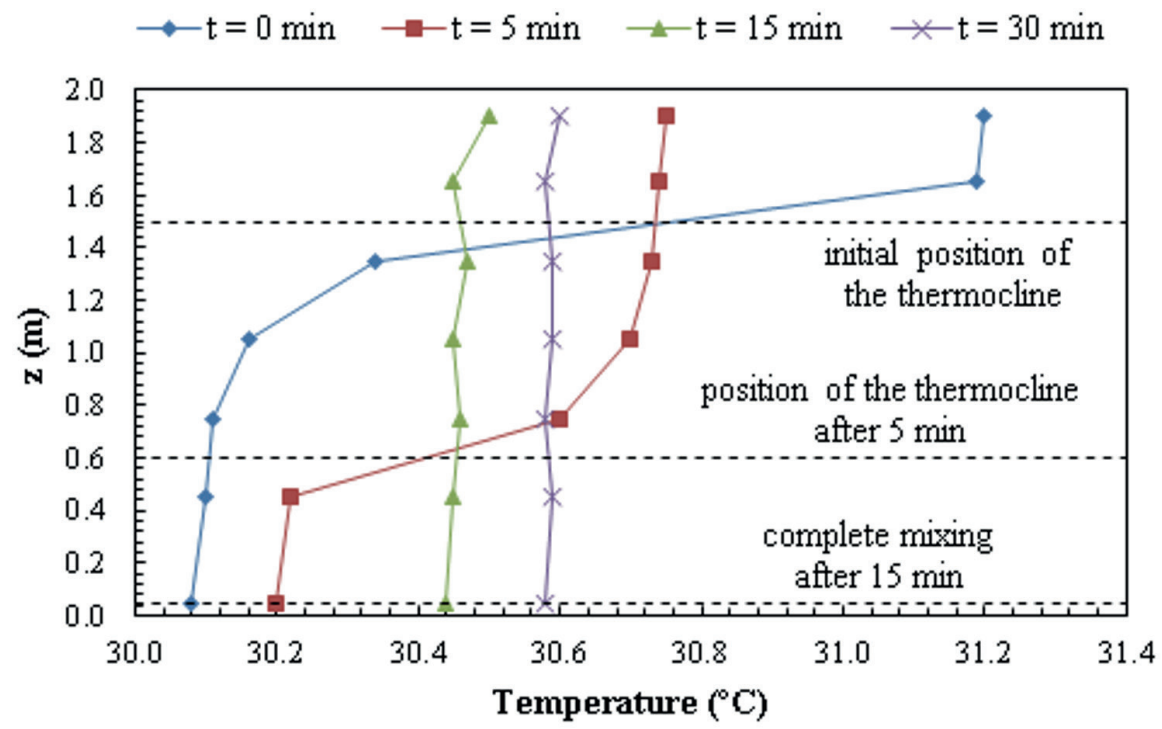

Figure 4 - Temporal evolution of the temperature profiles along the destratification process $\left(\mathrm{Q}=0.05 \mathrm{~m}^{3} / \mathrm{s}\right)$, which is expected to occur within the effective area A around the diffuser, as defined in Eq. (3).

laboratory scale. It is also important to mention that the characteristic velocity of the bubble plume $(\sim 1 \mathrm{~m} / \mathrm{s})$ was significantly higher than the shear velocity induced by the wind at the water surface $(\sim 0.01 \mathrm{~m} / \mathrm{s})$, which was estimated according to Fischer et al. (1979) for the measured wind speed (2 $\mathrm{m} / \mathrm{s}$ ). This confirms that the destratification process was dominated by the bubble plume.

Figure 6 shows a validation of the bubble plume destratification model with the field data shown in Fig. $4\left(\mathrm{Q}=0.05 \mathrm{~m}^{3} / \mathrm{s}\right)$. Mean deviations between modelled and measured data were within $\pm 20 \%$ for all the tests. Therefore, it can be inferred that the model proposed here can potentially simulate the destratification process induced by bubble plumes in lakes and reservoirs. Observe that this model is an extension of that of Lima Neto (2012), which was developed initially for unstratified flows, and that of Lima Neto et al. (2016), which was validated only with laboratory data.

After validation of the model, it was used to predict the impact of destratification on the net reduction of water surface temperature during a typical day in the Santo Anastácio Lake. Hence,

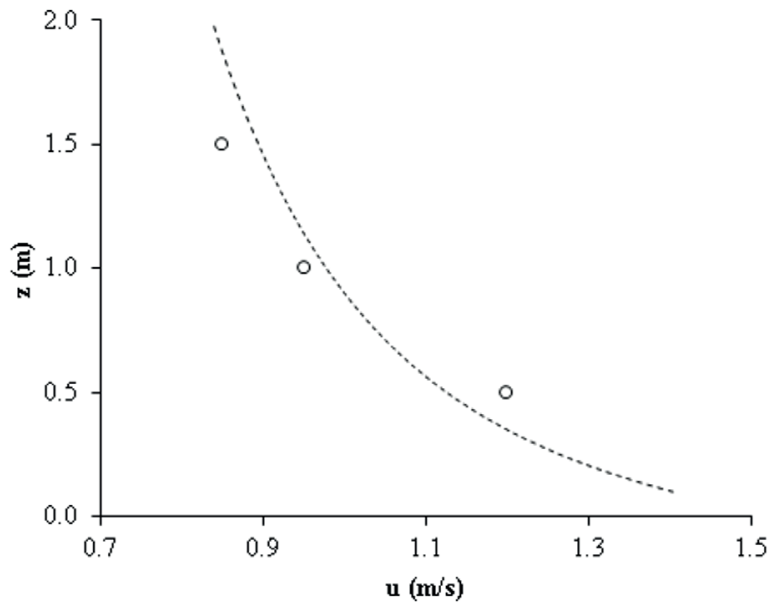

Figure 5 - Comparison of measured (circles) and simulated (dashed line) water velocities at the bubble plume centreline $\left(\mathrm{Q}=0.05 \mathrm{~m}^{3} / \mathrm{s}\right)$.

temperature measurements provided by Pacheco and Lima Neto (2017) were used as a baseline. Figure 7 shows a comparison of the time-evolution of the surface temperature measured (under natural conditions) and modelled considering intermittent release of the bubble plume with $Q=0.05 \mathrm{~m}^{3} / \mathrm{s}$. Note that here a temperature difference $\left(T_{e}-T_{h}\right)$ of $1{ }^{\circ} \mathrm{C}$ was considered constant during the day time under natural conditions. In addition, as a worstcase scenario, it was assumed that every time the 


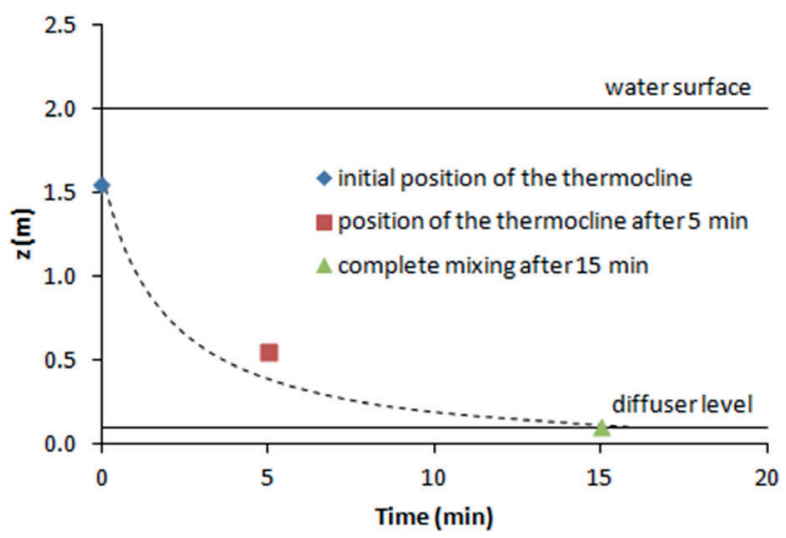

Figure 6 - Validation of the bubble plume destratification model with field data $\left(\mathrm{Q}=0.05 \mathrm{~m}^{3} / \mathrm{s}\right)$. Dashed line indicates model simulation and symbols indicate measurements.

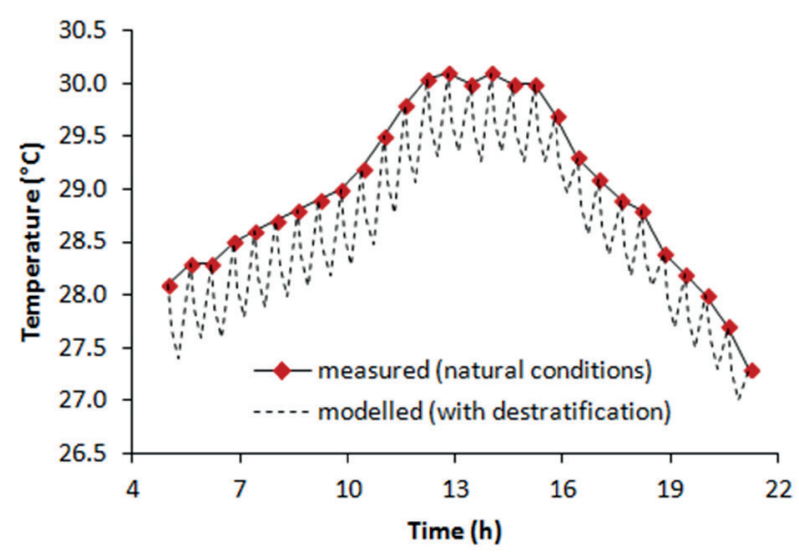

Figure 7 - Comparison of the time-evolution of the water surface temperature measured by Pacheco and Lima Neto (2016), under natural conditions, and the surface temperature modelled considering intermittent destratification $(\mathrm{Q}=0.05$ $\left.\mathrm{m}^{3} / \mathrm{s}\right)$.

bubble plume system was turned off (after $15 \mathrm{~min}$ of operation), the water temperature returned to its natural two-layer stratified condition because of the heat exchange with the water surface and the lake bed. The simulation resulted in a net temperature reduction of about $0.4^{\circ} \mathrm{C}$. This confirms that bubble plume destratification can potentially reduce the temperature of the water surface by approximately $1 / 2$ of its initial temperature difference $\left(\mathrm{T}_{\mathrm{e}}-\mathrm{T}_{\mathrm{h}}\right)$. Similar trends as that depicted in Fig. 7 were also reported by Van Dijk and Van Vuuren (2009) by using intermittent release of the bubble plume (every $10 \mathrm{~min}$ ) in a South African reservoir. Nevertheless, negligible net temperature reductions were obtained numerically by Helfer et al. (2011) in an Australian reservoir by coupling a bubble plume model to a lake hydrodynamic model (DYRESM). This may be attributed to a faster rate of heat transfer to the surface waters (probably due to higher wind speed and lower water turbidity), resulting in a thicker epilimnion of about $2 / 5-1 / 2$ of the total water depth $h$, as compared to the one observed here (i.e. h/5). Additionally, Helfer et al. (2011) adopted continuous operation for long-term destratification of the reservoir (up to about six months) instead of intermittent bubbling for shortterm destratification, as in the present study.

Now the model can be used to predict the destratification time of the ten reservoirs selected in the present study (see Table I). The idea was to obtain the air flow rates $\mathrm{Q}$ that resulted in relatively short destratification times (up to about $2 \mathrm{~h}$ ), so that the bubble plumes could be released intermittently, as proposed in Fig. 7. For simplicity, a thermocline with thickness of $1 / 5$ of the water depth $h$ was considered for all reservoirs, in agreement with the temperature profile shown in Fig. 4 and those presented by Souza Filho et al. (2003) and Dantas et al. (2011). In practice, this system could be installed in the deeper portion of the lake, assuming arrays of bubble plumes spaced h apart, as suggested by Lima Neto et al. (2016). Figure 8 shows an example of the effect of the air flow rate Q per bubble plume on the deepening of the thermocline of the Orós reservoir. It is clearly seen that the destratification time can vary from about 1 to $4 \mathrm{~h}$ when $Q$ ranges from 0.1 to $10 \mathrm{~m}^{3} / \mathrm{s}$, respectively. Table II shows the values of $Q$ for each reservoir to reach complete mixing after $2 \mathrm{~h}$ of operation of the bubble plumes. Observe that these flow rates are proportional to the water depth, and may not be economically viable for relatively deep reservoirs with small capacities, such as Prazeres and Canoas. As a comparison, the air flow rate per plume of the Orós reservoir $\left(0.7 \mathrm{~m}^{3} / \mathrm{s}\right)$ is of the same order as 


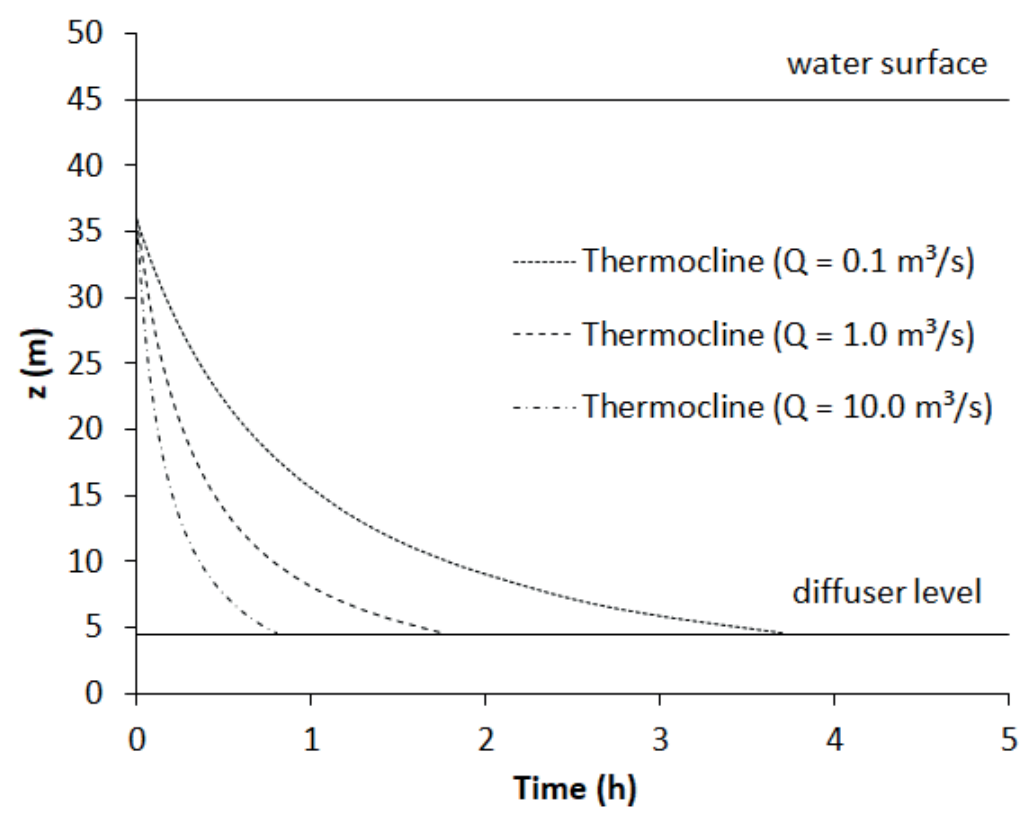

Figure 8 - Simulation of the effect of different air flow rates $Q$ on the deepening of the thermocline of the Orós reservoir.

those reported by Boegman and Sleep (2012) for long-term destratification of Central Lake Eire, but 35-70 times larger than those of Helfer et al. (2011) for destratification of an Australian reservoir with similar capacity $\left(1,160 \mathrm{hm}^{3}\right)$ and maximum water depth (40 m) of the above-mentioned reservoir.

Souza Filho et al. (2003), Meireles et al. (2007) and Dantas et al. (2011) found temperature differences between the epilimnion and hypolimnion $\left(\mathrm{T}_{\mathrm{e}}-\mathrm{T}_{\mathrm{h}}\right)$ ranging from about 1 to $5^{\circ} \mathrm{C}$ for reservoirs located in the Brazilian Northeast, with water depths $h$ varying from about 10 to 45 $\mathrm{m}$. Thus, bubble plume destratification of the ten selected reservoirs (see Table I) was modelled here considering typical temperature differences of $2^{\circ} \mathrm{C}$ and $4^{\circ} \mathrm{C}$ and the flow conditions of Table II. This resulted in surface temperature drops ranging from about $1^{\circ} \mathrm{C}$ to $2^{\circ} \mathrm{C}$, similarly to the results shown in Fig. 7 for the Santo Anastácio Lake. Therefore, the study of evaporation suppression of the selected reservoirs will be carried out considering two scenarios of temperature reduction: $-1^{\circ} \mathrm{C}$ and $-2^{\circ} \mathrm{C}$. The effects of different conditions of air flow rates/ intermittent bubbling and uncertainties related to the meteorology/stratification patterns are estimated to affect these temperature reductions $\left(-1^{\circ} \mathrm{C}\right.$ and $-2^{\circ} \mathrm{C}$ ) in up to about $\pm 50 \%$. Figure 9 shows as an example the data of precipitation and evaporation for the Trussu reservoir, which was obtained from Campos et al. (2016), in addition to predictions of evaporation suppression by using Eqs. (5) and (6), considering drops of -1 and $-2{ }^{\circ} \mathrm{C}$ in the temperature of the epilimnion $\mathrm{T}_{\mathrm{e}, \mathrm{i}}$ (assumed an average of $28^{\circ} \mathrm{C}$ ). The results indicate reductions in the net evaporation of $5.7 \%$ and $11.1 \%$, respectively. The same procedure was adopted for the other reservoirs selected in the present study, and similar evaporation reductions were obtained (5-12\%), as the temperature of the epilimnion $\mathrm{T}_{\mathrm{e}, \mathrm{i}}$ did not change significantly $\left(26-31^{\circ} \mathrm{C}\right)$ among reservoirs. These results corroborate the simulations of Cox (1999), in which evaporation suppressions of about 10\% were obtained for reservoirs in Cyprus. Observe that other equations provided by Fischer et al. (1979) and Maidment (1993) for estimating the saturation vapour $\left(\mathrm{e}_{\mathrm{s}, \mathrm{i}}\right)$ were also tested here, but the deviations in the evaporation reductions were within about $\pm 2 \%$. 
TABLE II

Estimated air flow rates $Q\left(\mathrm{~m}^{3} / \mathrm{s}\right)$ for complete destratification of the selected reservoirs (to reach complete mixing after 2 hours).

\begin{tabular}{cccccccccc}
\hline Ema & Ingazeiro & Cipoada & Trapiá II & Prazeres & Canoas & Cedro & Trussu & Pedras Brancas & Orós \\
\hline 0.005 & 0.011 & 0.003 & 0.060 & 0.780 & 0.590 & 0.009 & 0.180 & 0.092 & 0.710 \\
\hline
\end{tabular}

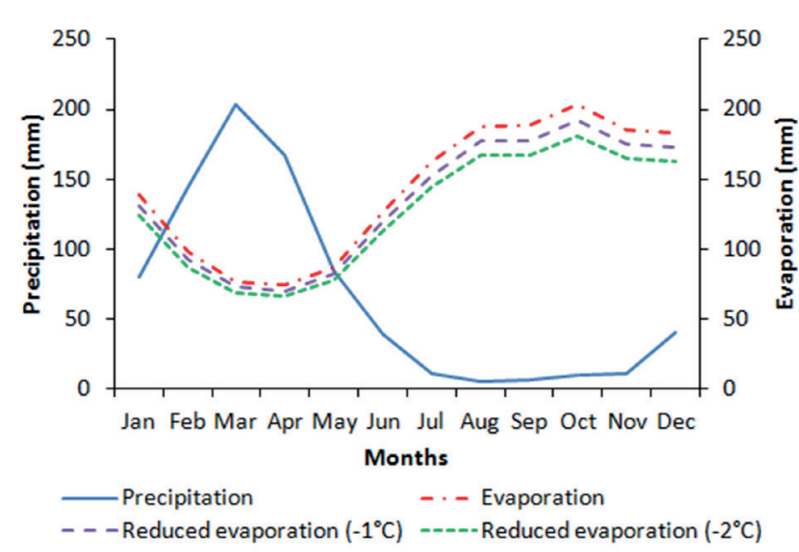

Figure 9 - Time series of precipitation and evaporation for the Trussu reservoir, including the predicted impact of evaporation reduction as a result of drops of -1 and $-2^{\circ} \mathrm{C}$ in the temperature of the epilimnion $\left(\mathrm{T}_{\mathrm{e}, \mathrm{i}}\right)$.

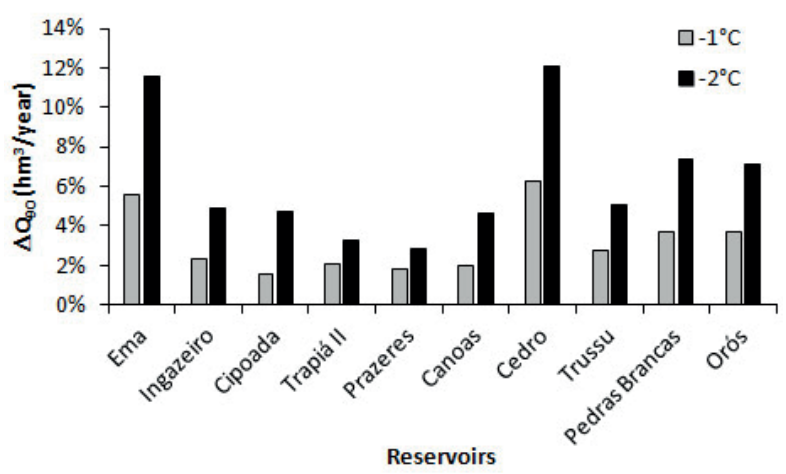

Figure 10 - Impact of temperature reductions $\left(-1{ }^{\circ} \mathrm{C}\right.$ and $\left.-2^{\circ} \mathrm{C}\right)$ on the regulated flow $\mathrm{Q}_{90}$ of the selected reservoirs.

Figure 10 shows the impact of temperature reductions $\left(-1^{\circ} \mathrm{C}\right.$ and $\left.-2{ }^{\circ} \mathrm{C}\right)$ due to artificial destratification on the regulated flow $\mathrm{Q}_{90}$ of the selected reservoirs, by solving the water budget equation [Eq. (4)]. The results indicate increases in $\mathrm{Q}_{90}$ ranging from 1.6 to $12.1 \%$, which represents additional water availabilities per reservoir varying from about 0.1 to $27 \mathrm{hm}^{3} /$ year.

Curve fitting indicates that the increase in $\mathrm{Q}_{90}$ for each reservoir can be approximated by a line, with the coefficient of determination $\left(\mathrm{R}^{2}\right)$ for all the ten cases ranging from 0.9660 to 0.9996 . This resulted in the following general curve that can be used to predict the increase in the regulated flow as a function of $\mathrm{Q}_{90}$ and $\Delta \mathrm{T}$ :

$Q_{90, \Delta T}=Q_{90}(1+0.0356 \Delta T)$

The fit of this general curve [Eq. (7)] to the simulated data is shown in Fig. 11. Again, a very good agreement has been obtained, with $\mathrm{R}^{2}$ $=0.9998$. This suggests that Eq. (7) can be used to provide estimates of the influence of $\Delta \mathrm{T}$ on reservoir yield, including not only the effect of destratification, but also possible effects resulting from other anthropogenic/natural impacts on water temperature.

As an application of the results obtained in the present study, Eq. (7) can be used for example to predict the effect of evaporation suppression due to artificial destratification on the increase in the regulated flow of a eutrophic reservoir - Orós, located in the rural area of the State of Ceará. The recommendation is to use the air diffuser system intermittently during the day time: keep on pumping for 2 hours, stop for the same time ( 2 hours) and then start over the process until a total duration of 12 hours (solar exposure period) is reached. Hence, assuming an average temperature difference between the epilimnion and hypolimnion $\left(\mathrm{T}_{\mathrm{e}}-\mathrm{T}_{\mathrm{h}}\right)$ of $1.5^{\circ} \mathrm{C}$, an array of $\mathrm{n}=225$ air diffusers spaced $40 \mathrm{~m}$ apart, and an air flow rate per diffuser $\mathrm{Q}=$ $0.7 \mathrm{~m}^{3} / \mathrm{s}$, it is expected a daily average temperature reduction of about $0.5^{\circ} \mathrm{C}$. This would result, in turn, in an increase in the regulated flow of $6.8 \mathrm{hm}^{3} /$ year, which could supply around 125,000 inhabitants per year. Now, following Helfer (2012), the compressor power can be calculated by $\mathrm{P}=2.3 \mathrm{nQ} \rho_{\mathrm{a}} \mathrm{h} \ln (\mathrm{h} /$ 


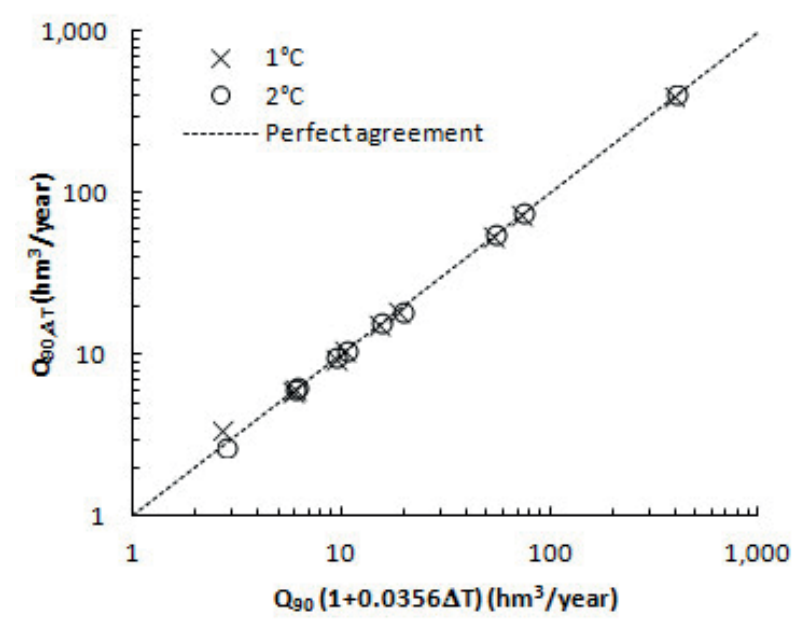

Figure 11 - General curve to describe the increase in the regulated flow as a function of $\mathrm{Q}_{90}$ and $\Delta \mathrm{T}$.

$h_{a}$ ), in which $h_{a}$ is the atmospheric pressure head. Thus, the operation of the above-mentioned system would require a total power $\mathrm{P}$ of about $35 \mathrm{MW}$, or $18 \mathrm{~W}$ for destratification of $1,000 \mathrm{~m}^{3}$, which is about 4 times larger than the value reported by Van Dijk and Van Vuuren (2009) for a shallower reservoir (about $5 \mathrm{~m}$ deep). Thus, assuming a rural electricity tariff of $0.06 \mathrm{US} \$ / \mathrm{kWh}$, it is estimated a unit operational cost of about $1.2 \mathrm{US} \$ / \mathrm{m}^{3}$ for the proposed destratification system. This cost is much lower than that for water distribution by trucks ( $7 \mathrm{US} \$ / \mathrm{m}^{3}$ ), which are commonly used in the rural areas of the Brazilian Northeast (see Araújo et al. 2003). On the other hand, the cost is of the same order of that for a desalination plant $(\sim 1 \mathrm{US} \$$ / $\mathrm{m}^{3}$ ) that is currently being installed by the Ceará State Water Company (CAGECE) in the coastal city of Fortaleza, capital of Ceará. Nevertheless, the Orós reservoir is located about $250 \mathrm{~km}$ from the coast, which would result in much more expensive water pumping from the sea to meet the rural demands. Moreover, the destratification system is also expected to improve water quality (and increase water availability), while the desalination plant can cause significant environmental impacts. Although the pumping system proposed in this study appears to be relatively large, the total air flow rate of $157.5 \mathrm{~m}^{3} / \mathrm{s}$ is within the values of 16 $2,500 \mathrm{~m}^{3} / \mathrm{s}$ proposed by Boegman and Sleep (2012) for long-term destratification of Central Lake Eire. This system may also become more attractive with the fast development of more efficient renewable energy techniques. Additionally, different diffuser designs can be used to prevent clogging, enhance oxygen transfer and improve the efficiency of the destratification system (Lima and Lima Neto 2018).

\section{CONCLUSIONS}

Results from field surveys performed in a hypereutrophic lake in the Brazilian semiarid showed that artificial destratification induced by bubble plumes promoted a surface water temperature reduction of $0.3-0.6^{\circ} \mathrm{C}$ for different flow conditions. The time-evolution of the temperature profile in this lake, in addition to water velocity measurements, were used for validation of an integral bubble plume model, which was used to predict the destratification process in ten selected water-supply reservoirs with capacities of $10-1,956 \mathrm{hm}^{3}$. The results suggested net temperature reductions of up to about $1.0^{\circ} \mathrm{C}$, which potentially reduced evaporation rates by up to approximately $10 \%$. Then, hydrological modelling showed that artificial destratification increased water availability from about 2 to $12 \%$ of the regulated flow of these reservoirs. The simulated data could also be converted into a single empirical correlation that can be used to predict the impact of temperature reduction on the regulated flow. Finally, a simplified feasibility analysis yielded a unit operational cost of $1.2 \mathrm{US} \$ / \mathrm{m}^{3}$, which suggests that artificial destratification may be considered as an alternative to increase water availability in rural dry areas, notably in eutrophic reservoirs.

\section{ACKNOWLEDGMENTS}

The author appreciates the financial support from the Conselho Nacional de Desenvolvimento Cientifico 
e Tecnológico/CNPq (Project \# 476430/20119) and from the Fundação Cearense de Apoio ao Desenvolvimento Científico e Tecnológico/ FUNCAP (Project \# PNE-0112-00042.01.00/16).

\section{REFERENCES}

ARAÚJO JC, ABREU CBR, BARBOSA CP AND JOCA ELL. 2003. Assessment of Water Costs in Semiarid Brazil. In: Global Change and Regional Impacts - Water Availability and Vulnerability of Ecosystems and Society in the Semiarid Northeast of Brazil, (Eds) Gaiser T, Krol M, Frischkorn H, Araujo JC and Springer-Verlag, 435 p.

ASSOULINE S, NARKIS K AND OR D. 2011. Evaporation suppression from water reservoirs: Efficiency considerations of partial covers. Water Resour Res 47: W07506.

BOEGMAN L AND SLEEP S. 2012. Feasibility of Bubble Plume Destratification of Central Lake Erie. J Hydraul Eng 138: 985-989.

BORMANS M, MARŠÁLEK B AND JANČULA D. 2016. Controlling internal phosphorus loading in lakes by physical methods to reduce cyanobacterial blooms: A review. Aquat Ecol 50(3): 407-422.

BOUVY M, FALCÃO D, MARINHO M, PAGANO MAND MOURA A. 2000. Occurrence of Cylindrospermopsis Cyanobacteria in 39 Brazilian tropical reservoirs during the 1998 drought. Aquatic Microb Ecol 23: 13-27.

CAMPOS JNB, LIMA NETO IE, STUDART TMC AND NASCIMENTO LSV. 2016. Trade-off between reservoir yield and evaporation losses as a function of lake morphology in semi-arid Brazil. An Acad Bras Cienc 88: 1113-1126.

CAMPOS JNB, SOUZA FILHO FA AND LIMA HVC. 2014. Risks and uncertainties in reservoir yield in highly variable intermittent rivers: case of the Castanhão Reservoir in semi-arid Brazil, Hydrolog Sci J 59(6): 11841195.

CAMPOS JNB AND STUDART TMC. 2006. Hidrologia de reservatórios: a construção de uma teoria. ASTEF, 285p (in Portuguese).

COX CW. 1999. Water Supply Enhancement in Cyprus through Evaporation Reduction. M. Eng. Thesis, MIT. (Unpublished).

DANTAS EW, MOURA AN AND BITTENCOURTOLIVEIRA MC. 2011. Cyanobacterial blooms in stratified and destratified eutrophic reservoirs in semi-arid region of Brazil. An Acad Bras Cienc 83: 1327-1338.

FISCHER HB, LIST EJ, KOH RCY, IMBERGER J AND BROOKS NH. 1979. Mixing in Inland and Coastal Waters. Academic Press, 483 p.

HELFER F. 2012. Influence of air-bubble plumes and effects of climate change on reservoir evaporation. $\mathrm{PhD}$ Thesis, Griffith University.
HELFER F, ZHANG H AND LEMCKERT C. 2011. Modelling of lake mixing induced by air-bubble plumes and the effects on evaporation. J Hydrol 406: 182-198.

IMTEAZ MA AND ASAEDA T. 2000. Artificial mixing of lake water by bubble plume and effects of bubbling operations on algal bloom. Water Res 34: 1919-1929.

LIMA DD AND LIMA NETO IE. 2018. Effect of nozzle design on bubbly jet entrainment and oxygen transfer efficiency. J Hydraulic Eng 144(8): 1-8.

LIMA NETO IE. 2012. Bubble plume modelling with new functional relationships. J Hydraulic Res 50: 134-137.

LIMA NETO IE, CARDOSO SSS AND WOODS AW. 2016. On mixing a density interface by a bubble plume. J Fluid Mech 802, R3.

LIMA NETO IE, WIEGAND MC AND ARAÚJO JC. 2011. Sediment redistribution due to a dense reservoir network in a large semiarid Brazilian basin. Hydrolog Sci J 56: 319-333.

LIMA NETO IE, ZHU DZ AND RAJARATNAM N. 2008. Effect of tank size and geometry on the flow induced by circular bubble plumes and water jets. J Hydraulic Eng 134(6): 833-842.

MAIDMENT DR. 1993. Handbook of Hydrology, McGrawHill, 1424 p.

MEIRELES ACM, FRISCHKORN H AND ANDRADE EM. 2007. Sazonalidade da qualidade das águas do açude Edson Queiroz, bacia do Acaraú, no semiárido cearense. Rev Ciênc Agron, 38(1): 25-31 (in Portuguese).

PACHECO CHA AND LIMA NETO IE. 2017. Effect of artificial circulation on the removal kinetics of cyanobacteria in a hyper-eutrophic shallow lake. J Environ Eng 143(12): 1-8.

SILANS AMBP. 2003. Redução da Evaporação de Açudes O Estado da Arte. Rev Bras Recur Hídricos 8(2): 101-109 (in Portuguese).

SOUZA FILHO FA, MARTINS ESPR AND PORTO M. 2003. O Processo de Mistura em Reservatórios do SemiÁrido e sua Implicação na Qualidade da Água. Rev Bras Recur Hídricos 11(4): 109-119. (in Portuguese).

SRH. 1992. Plano Estadual de Recursos Hídricos. Secretaria de Recursos Hídricos do Estado do Ceará - SRH, Fortaleza.

TONÉ AJ, PACHECO CHA AND LIMA NETO IE. 2017. Circulation induced by diffused aeration in a shallow lake. Water SA 43: 36-41.

VAN DIJK M AND VAN VUUREN SJ. 2009. Destratification induced by bubble plumes as a means to reduce evaporation from open impoundments. Water SA 35(2): 158-167.

VISSER PM, IBELINGS BW, BORMANS M AND HUISMAN J. 2016. Artificial mixing to control cyanobacterial blooms: a review. Aquat Ecol 50(3): 423-441.

WOODS AW. 2010. Turbulent Plumes in Nature. Annu Rev Fluid Mech 42: 391-412.

WÜEST A, BROOKS NH AND IMBODEN DM. 1992. Bubble plume modeling for lake restoration. Water Resour Res 28: 3235-3250.

WURBS RA AND AYALARA. 2014. Reservoir evaporation in Texas, USA. J Hydrol 510: 1-9. 